\title{
The Impact of Enterprise Risk on Firms' Performance: An Empirical Analysis of Indonesia's Public Listed Banking Firms
}

\author{
Mariana Ing Malelak ${ }^{1^{*}}$ and Fiany Pryscillia ${ }^{1}$ \\ ${ }^{1}$ Finance Program, Faculty of Business and Economics, Petra Christian University, \\ Jl. Siwalankerto 121-131, Surabaya 60235, Indonesia
}

\begin{abstract}
This paper examines the influential factors of potential adoption of Enterprise Risk Management (ERM) and the impact of ERM adoption on the public listed banking firms' performances in Indonesia during 2009 to 2017. This research uses logistic regression to test four potential factors as the driving forces behind the potential adoption of ERM and linear regression to test the impact of ERM on firms' performances. The result suggests that firms with greater size, having more institutional ownership, and being part of Multinational companies are more likely to adopt ERM, while the implementation of ERM has no significant impact on the firms' performance. Little empirical research has been conducted on the topic, especially in developing economies like Indonesia. This study will broaden the scope of literature by providing novel empirical evidence.
\end{abstract}

Keywords: Bank performance, enterprise risk management adoption, firm size, institutional ownership,

\section{Introduction}

Liberalization has made economics becoming more complex and volatile so that the risk faced by economic agents arising [1]. Reliable risk management is one of the core competencies that should be conducted by management to create the value of a company. Unlike the traditional "silo-based" approach, the Enterprise Risk Management (ERM) enables firms to manage risk through an integrated approach. Despite the heightened interest in ERM by academics and practitioners, empirical evidence regarding the determinants of these programs lacks, especially in emerging country like Indonesia. The firms with high financial leverage tend to implement ERM in their risk oversight [2]. The firms with higher financial leverage and with a Big Four auditors are more likely to have a form of an ERM framework in place [3]. This research study focuses on one of the quickest developing economies, namely Indonesia, as known as Southeast Asia's largest economy [4]. Throughout this study, the determinants of potential adoption of ERM will be identified. The effectiveness of risk management is crucial in the banking companies to support decision-making by balancing the tradeoff between risk and expected return in a more precise way in order to improve the company's performance [5]. The ERM

\footnotetext{
* Corresponding author: mariana.ing@petra.ac.id
} 
framework, namely The Return Driven Strategy, which is an effective tool in integrating strategic objectives and risk management which facilitate firms to be able to respond risk more effectively and increase potential return, hence it may create value of a company [6]. The second model was built to test the impact of the ERM adoption on public listed banking firms' financial performance in Indonesia.

\section{Literature review and hypotheses}

Risk is an integral part of the business. Risk management is a continuous, forward-looking process that is an important part of business and technical management processes. If traditional risk management enabled managers to manage risk separately and was oriented only at protection against the risk of negative impacts, now under the ERM system, all the risks are managed as a single strategic enterprise-wide integrated systems and further it may improve the decision process with respect to strategic and operational developments [7]. Enterprise Risk Management (ERM) is defined as the process, effected by an entity's board of directors, management and other personnel, applied in strategy setting and across the enterprise, designed to identify potential events that may affect the entity, and manage risk to be within its risk appetite, to provide reasonable assurance regarding the achievement of entity objectives [8]. ERM framework is integrated into the parent organization's strategy, operational policies, as well as practical applications.

\subsection{Stock price volatility}

Volatility of stock price, which is the fluctuations in a company's stock price movement, regarded as a form of uncertainty in the company's performance. High volatility made investors leave the market to sell assets to minimize investment risk [9]. Conversely, a low stock price volatility illustrates the relatively stable company's financial performance, hence gives a positive signal to investors [10]. Therefore, the company management sees the need to implement ERM in order to stabilize the company's stock price movements. The stock price volatility have not found significant influence to the potential adoption ERM [2,3].

H1: Firms with higher stock price volatility are more likely to adopt ERM

\subsection{Firm size}

Large companies' business activities as well as the types of transactions are more diverse and more complex than the smaller size company [11]. Risks faced by large enterprises are also more diverse than the possibility of the risk borne by small firms [12]. Additionally, larger firms are able to dedicate greater resources on more diversified alternative investments [3]. Consistent with these theories, found that firm size has a positive significant influence on the implementation of ERM in US Insurers [13].

$\mathrm{H}$ 2: Larger firms are more likely to implement ERM

\subsection{Institutional ownership}

As today's business are becoming more complex, the demands of shareholders on corporate disclosure are also increasingly intense, especially about the nature and level of risks faced by the company. Institutional shareholders, with the magnitude of the portion of ownership of shares owned, relatively has a greater influence than the individual shareholders and can give more impetus in the implementation of ERM in the company to ensure that the risks remain within tolerable limits of owners [2]. This factor has been investigated the institutional ownership. Only the first has concluded the significant influence to adopt ERM $[3,13]$. 
H3: Firms with higher percentage of institutional ownership are more likely to adopt ERM

\subsection{Firm as part of the multinational company}

Multinational companies (MNC) faced the risk arising from changes in exchange rates, such as the translation exposure, since there are differences in currency used in each country where the unit of the company operates, as well as country risk due to the diverse government regulations in each country [14]. The risk will potentially reduce the income which will affect the company's profitability as well as the overall condition of the company. Therefore, ERM is needed to anticipate the risks associated with the economic policy differences between countries and the risk of exchange rate movements.

H4: Firms as part of the Multinational Company are more likely to adopt ERM

The ultimate purpose of the ERM's implementation is to maximize the shareholders' wealth in an ethical manner. The Return Driven Strategy, one of the ERM framework, is an effective tool in integrating the company's strategic objectives with risk management objectives [6]. The method enables the management to respond to the risk more effectively, thus increasing potential return of the firm. The company's resource allocation based on risk can maximize the probability of gaining the return and achieve the business objectives [15]. Therefore, effective implementation of ERM can increase the company's financial performance, hence it can increase firms' ROA (Return on Assets), as the measurement of how efficient management of the company utilizes assets to generate income [16].

H5: Firms which implement ERM under their risk management have a higher ROA

The application of ERM can stabilize earnings [5]. The stability of earnings indicates the firms have good performance thus creating demand for the company's stock. Resources in the form of such investments can be allocated to develop operational and technologies, hence will improve the company's performance. Good risk management will enable the management of the company to improve the efficiency of capital, therefore firms are expected to operate more optimally and at the end will increase the profit [2]. Therefore, the implementation of ERM will enhance the company's ROE, which indicate how the stockholders fared during the year [16].

H6: Firms which implement ERM under their risk management have a higher ROE

\section{Methodology}

In this research, the sample was derived from the banking firms which listed in Bursa Efek Indonesia (BEI) during 2009 to 017 . By the time this study was conducted, there are totally 30 banking firms listed in BEI. Then the samples will be eliminated using two criteria as mentioned below:

(i). Firms must publish their annual report and financial report regularly during the period 2009 to 2017

(ii). The company's stock price data is fully available during the period 2009-2017

By following the above criteria, the final sample resulted in totally 12 firms.

The necessary data are collected from several relevant information providers. The company's annual report and financial statement are collected from idx.co.id, icamels.id, financial data from Bloomberg Terminal, closing stock price from yahoofinance.com. The research will follow the steps as shown in the Figure 1. 


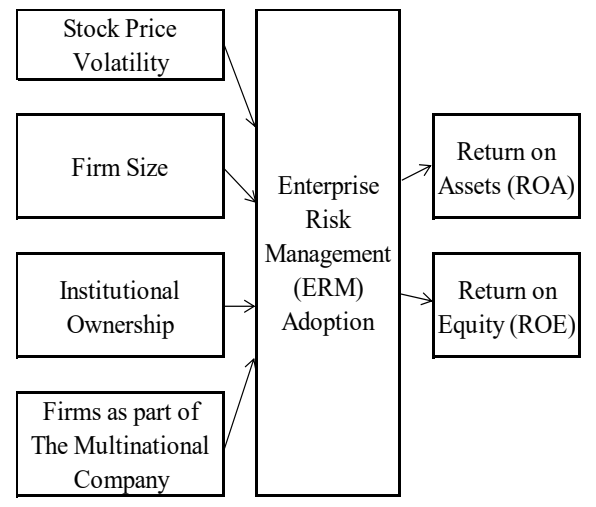

Fig. 1. Conceptual framework

As for the logistic regression equation for the research model / Equation 1 is:

$\mathrm{Ln} \mathrm{P} /(1-\mathrm{P})=\beta 0+\beta 1$ volt $-1+\beta 2$ sizet $-1+\beta 3$ instt $-1+\beta 4$ mnct- 1

and the linear regression equations for the second and third models are:

$\mathrm{ROA}_{\mathrm{t}}=\beta_{0}+\beta_{1} \mathrm{ERM}_{\mathrm{t}}$

$\mathrm{ROE}_{\mathrm{t}}=\beta_{0}+\beta_{1} \mathrm{ERM}_{\mathrm{t}}$

The operational defenition of the research variables and indicators for measurement included in this research on Figure 1. Stock price volatility (Vol) define as movement of stock prices measures by the root of the difference of square weekly stock price of the stock divided by the number of observations. Firm size (size) definition as a logarithm of the total assets of the company. Institutional ownership (Inst) define as the percentage of shares owned by institutions and government. Firms as part of the multinational company define as a whether or not the company's operating business units located in other countries. Enterprise risk management are ERM implementation in a banking services firm. Return on assets are the ratio between net income and total assets of the company in the same period. Return on equity define are the ratio between net profit and total equity of companies in the same period.

\section{$4 \quad$ Findings and discussion}

Table 1 presents the result of the descriptive statistics of model 1.

Table 1. Descriptive Statistics of Logistic Regression Model

\begin{tabular}{|c|c|c|c|c|}
\hline Variables & Mean & Max. & Min. & N \\
\hline ERM & 0.625 & 1.000 & 0.000 & 108 \\
\hline VOL & 0.075 & 0.420 & 0.000 & 108 \\
\hline SIZE & 15.441 & 16.837 & 12.126 & 108 \\
\hline INST & 0.728 & 0.980 & 0.067 & 108 \\
\hline MNC & 0.435 & 1.000 & 0.000 & 108 \\
\hline
\end{tabular}

The number of data is 108 in accordance with the total observations firms (12 sample firms) times the number of periods (2009 to 2017). The mean, maximum value, minimum value, and standard deviation of variables used in the first model are presented in Table 1.

The model was first tested whether it has fitted or not using Hosmer and Lemeshow Test. The result of Goodness of Fit (GOF) test along with Nagelke R Square, is shown in Table 2: 
Table 2. Hosmer \& Lemeshow and Nagelkerke R Square Test

\begin{tabular}{|l|c|}
\hline Sig. Value of Hosmer and Lemeshow Test & $0.165 *$ \\
\hline Nagelkerke R Square & 0.448 \\
\hline *Significant difference of means at 5 \% level
\end{tabular}

The p-value of Hosmer and Lemeshow test results in 0.165 , which exceeds the confidence of interval $(\alpha)$ of $5 \%$. It can be concluded that the model was feasible according to the GOF criteria. The independent variables are able to explain their influence on the probability of the dependent variable as big as $44.8 \%$.

The omnibus test was conducted in order to test the influence of all independent variables simultaneously to the dependent variable. The result is attached in Table 3:

Table 3. Result of Omnibus Test of Model Coefficients

\begin{tabular}{|l|l|}
\hline Sig. Value of Omnibus Test of Model Coefficients & $0.000 *$ \\
\hline
\end{tabular}

The significant value of the Omnibus test is less than the significance level of $5 \%$. It can be inferred that at least one variable of stock price volatility, firm size, institutional ownership, and firm as part of the Multinational Company is having a significant influence on the adoption of ERM. Therefore the logistic regression model is feasible.

The result of the logistic regression test is presented in Table 4:

Table 4. Result of Logistic Regression

\begin{tabular}{|c|c|c|c|c|}
\hline Variables & $\boldsymbol{\beta}$ & Wald & Sig. & $\operatorname{Exp~(\beta )}$ \\
\hline constant & -18.784 & & & \\
\hline Vol & -5.402 & 0.715 & 0.478 & 0.028 \\
\hline Size & 0.845 & 8.523 & $0.006^{*}$ & 2.313 \\
\hline Inst & 7.918 & 13.590 & $0.000^{*}$ & 628.771 \\
\hline MNC & 2.318 & 11.579 & $0.002^{*}$ & 10.524 \\
\hline
\end{tabular}

*Significant difference of means at $5 \%$ level

Based on the result in the Table 4, there are three contributing factors to ERM implementation, which are the firm size, institutional ownership, and firm as part of the Multinational Company. For each significant contributing factor, the relationship to potential ERM adoption is positive. It can be concluded that potential adoption of ERM is positively associated with being larger firms, having more institutional ownership proportions in the composition of firm's shareholder, and being part of the Multinational Company. In fact, as the size of the firm increased, the more complex the business activity run by the firm, hence the risk associated with it will be more diverse and threatening as well. Therefore, the implementation of good risk management through the ERM framework can be seen as the effort of the company to mitigate the risk and also show the commitment to the existing debtholders and shareholders.

Meanwhile, the influence of institutions in the adoption of ERM is consistent which concluded that institutions, with the huge proportions of the firm's ownership, are relatively more influential than individual shareholders and are able to exert greater pressure for the adoption of an ERM [13]. This statement is suitable with the data from public listed banking firms in Indonesia, where the average percentage of institutional ownership in Indonesia is around $72.8 \%$. ERM is applied to help managers control risk to be within the risk appetite of this dominant shareholders.

Lastly, the adoption of ERM is driven by the characteristic of the firm as the part of Multinational Company. Such firms must consider many financial factors that do not 
directly affect purely domestic firms. These include foreign exchange rates, differing interest rates from country to country, complex accounting methods for foreign operations, foreign tax rates, and foreign government intervention [17]. Therefore, ERM is needed to help managers to encounter the risk and transform it into the opportunity to gain.

Stock price volatility has no significant effect to the implementation of ERM in public listed banking firms in Indonesia. The stock price of the firms is formed based on the interaction between supply and demand in the market. Hence, Table 5 discussed about the t-test result of linear regression for the second and third model.

Table 5. Result of Second and Third Model using Linear Regression

\begin{tabular}{|c|c|c|}
\hline \multicolumn{3}{|c|}{ ROA MODEL } \\
\hline Variables & Coefficients & Sig. \\
\hline Constant & 0.025 & 0.000 \\
\hline ERM & 0.000 & 0.857 \\
\hline \multicolumn{3}{|c|}{ Dependent Variable: ROA } \\
\hline \multicolumn{3}{|c|}{ ROE MODEL } \\
\hline Variables & Coefficients & Sig. \\
\hline Constant & 0.220 & 0.000 \\
\hline ERM & -0.005 & 0.813 \\
\hline Dependent $\mathrm{Va}$ & $\mathrm{ROE}$ & \\
\hline
\end{tabular}

The p-values of ERM are 0.949 and 0.735 for each dependent variable, ROA and ROE consecutively. Both are greater than the confidence interval $(5 \%)$ therefore the result suggests that implementation of ERM does not have significant influence on banking firms' performance in Indonesia, measured by ROA and ROE.

There are at least four reasons to explain this insignificancy. First, the impact of ERM implementation can be observed in the long term, when firms have implemented ERM thoroughly within the firms' internal environment and communicated to all lines of management. In that case, we assume that firms are able to mitigate and adjust the risk, according to be within its risk appetite. This will lead firms to increase its cash flow and create competitive advantage in the long term. Since many banking firms had just applied ERM between 2014 to 2015, the expected results can not be observed in the period of observation.

Secondly, we can conclude that investors pay less attention to the ERM implementation as one of the considerable factors in making investment. Investors are more likely to consider other factors, such as the firm size and leverage [18].

The third reason is because firms that implementation of ERM in Indonesia is still very limited. Moreover, the level of implementation of risk management by companies in Indonesia is still low compared to other countries. Of the five levels of risk management level according to AON [19], Indonesia is still at level 1 and level 2, which is the level of initiation and involving. Association of Risk Management Practitioner (ARMP) stated that the high cost of obtaining the certificate of risk management processes, constrain the implementation of comprehensive risk management in a company [20]. These facts indicate that risk management has not been considered as a fundamental requirement companies in Indonesia. The managers of the firms have not maximized the potency in ERM to increase the value of the firm for the stakeholders' sake. Therefore, there is no significant influence of ERM implementation on the public listed banking firms' performance in Indonesia.

Fourth, in today's hyper-connected digital age, consumers expect their banks to deliver highly-personalized, high-tech services coupled with the convenience of anytime, anywhere banking. Digital Banking referred to the service given by banks which supported by the digital technology. Most bank firms have transformed to adjust into this trend. Many of them have started to implement this newly technology or at least upgrade their existing 
system. In addition to meet the wishes of customers, the banks use digital banking to improve efficiency, thus increasing the profitability. Therefore, digital banking has more contributing portion in current banks' profitability.

\section{Conclusion}

The main objective of this study was to identify the influential factors that encourage the implementation of ERM among banking firms in Indonesia. The result suggests that firm size, institutional ownership, and firm as part of the multinational company are the driven factors of ERM adoption. On the other hand, the result of this study also concluded that the implementation of ERM has no significant impact on banking firms' performance, measured by ROA and ROE.

This study indicates that firms should consider improving governance of their risk management, especially in the implementation of ERM, in order to maximize the potential of ERM that will increase firms' performance simultaneously and achieve its objectives.

It is recommended that future research can use more specific measurements for ERM variables, such as how well firms implement elements of ERM in its risk management to gain more insight into ERM implementation in firms. Moreover, future research should consider including other variables that have an impact on the firm's performance and also extend the period of observation.

\section{References}

1. S. Adiningsih, Koordinasi dan Interaksi Kebijakan Fiskal-Moneter: Tantangan ke Depan. [Coordination and interaction of fiscal-monetary policy: Challenges ahead.]. Yogyakarta: Kanisius (2012). [in Bahasa Indonesia]. http://lib.ui.ac.id/detail?id=20307633

2. A.P. Liebenberg, R.E. Hoyt, Risk Management and Insuranve Review, 6,1:3752(2003). https://onlinelibrary.wiley.com/doi/abs/10.1111/1098-1616.00019

3. N.M. Golshan, S.Z. Rasid, International Journal of Social, Behavioral, Educational, Economic, Business, and Industrial Engineering, 6:242-249(2012). https://pdfs.semanticscholar.org/9173/69d90e504c5515db883efbf7ce7b9bfb751b.pdf

4. World Bank. Countries/Indonesia World Bank. Retrieved October 9, 2018, [Online] from https://www.worldbank.org/en/country/indonesia (2018). [Accesed on 22 September 2016].

5. H.K., Mohammed, A. Knapkova, Procedia-Social and Behavioral Sciences, 220:271277(2016). https://www.sciencedirect.com/science/article/pii/S1877042816306000

6. M.S., Beasley, M.L. Frigo, ERM and its role in strategic planning and strategy execution. In: Enterprise Risk Management, J. Fraser, B.J. Simkins (Eds), Massachusetts: John Wiley \& Sons, Inc (2010). p. 31-50. https://onlinelibrary.wiley.com/doi/abs/10.1002/9781118267080.ch3

7. J. Fraser, B.J. Simkins, Enterprise risk management. Massachusetts: John Wiley \& Sons, Inc (2010). https://web.actuaries.ie/sites/default/files/ermresources/enterprise risk management_2010.pdf

8. COSO. Enterprise Risk Management - Integrated Framework. [Executive Summary]. USA: COSO (2004). p. 1-16. https://www.coso.org/Documents/COSO-ERMExecutive-Summary.pdf 
9. S. Situmeang, Analisis pengaruh volatilitas harga, likuiditas saham, EPS, size firm, momentum overnight terhadap return saham. [Analysis of the effect of price volatility, stock liquidity, EPS, size firm, overnight momentum on stock returns]. [Undergraduate Thesis], Faculty of Economics and Business, Universitas Diponegoro, Semarang, Indonesia (2015). [in Bahasa Indonesia]. http://eprints.undip.ac.id/46520/

10. A. Nair, E. Rustambekov, M. McShane, S. Fainshmidt, Managerial and Decision Economics, 35:555-566(2014).

https://onlinelibrary.wiley.com/doi/abs/10.1002/mde.2641

11. A. Witek-Crabb, Procedia - Social and Behavioral Sciences, 150:66-76(2014). https://doi.org/10.1016/j.sbspro.2014.09.008

12. S. Ahmad, C. Ng, L.A. McManus, Procedia-Social and Behavioral Sciences 164:541547(2014). https://doi.org/10.1016/j.sbspro.2014.11.144

13. R.E. Hoyt, D.L. Moore, A.P. Liebenberg, The value of enterprise risk management evidence from the US insurance industry. USA: Society of Actuaries (2008). p. 1-16. https:/www.soa.org/globalassets/assets/files/resources/essays-monographs/2008-ermsymposium/mono-2008-m-as08-1-hoyt.pdf

14. A.X. Huo, SOA-Risk Management, 27:23-24(2013). https://www.soa.org/globalassets/assets/library/newsletters/risk-managementnewsletter/2013/august/jrm-2013-iss27-hou.pdf

15. J.P. Toneguzzo, How to allocate resources based on risk. In: Enterprise Risk Management, J. Fraser, B.J. Simkins (Eds), Massachusetts: John Wiley \& Sons, Inc (2010). p. 189-217. https://onlinelibrary.wiley.com/doi/abs/10.1002/9781118267080.ch12

16. S. Ross, R. Westerfield, B. Jordan, Fundamentals of Corporate Finance, New York: McGraw Hill (2013). https://www.amazon.com/Fundamentals-Corporate-StandardMcGraw-Hill-Insurance/dp/0078034639

17. S. Ross, R. Westerfield, J. Jaffe, B. Jordan, Corporate Finance, New York: McGraw Hill (2010). https://www.mheducation.com/highered/product/corporate-finance-rosswesterfield/M9780077861759.html

18. C.K. Sanjaya, N. Linawati, FINESTA, 3,1:52-57(2015). [in Bahasa Indonesia]. http://publication.petra.ac.id/index.php/manajemen-keuangan/article/view/2975

19. AON. Global Enterprise Risk Management Survey. Kansas: AON (2010). http://www.aon.com/attachments/2010_Global_ERM_Survey.pdf

20. A.K. Bangun, Penerapan manajemen risiko di perusahaan publik masih rendah. [The application of risk management in public companies is still low], [Online] from https://investasi.kontan.co.id/news/penerapan-manajemen-risiko-di-perusahaanpublik-masih-rendah-1 (2011). [in Bahasa Indonesia]. [Accessed on October 14, 2018] 